\title{
SCAFFOLDING IN THE TEACHING OF WRITING DISCUSSION TEXTS BASED ON SFL-GENRE BASED APPROACH
}

\author{
Eva Fitriani Syarifah \\ Department of English Education, Indonesia University of Education \\ E-mail: eva.fsyarifah@gmail.com \\ Wawan Gunawan \\ Department of English Education, Indonesia University of Education \\ E-mail: wagoen@yahoo.com
}

APA Citation: Syarifah, E. F. \& Gunawan, W. (2015). Scaffolding in the teaching of writing discussion texts based on SFL-genre based approach. English Review, 4(1), $39-53$

\begin{abstract}
:
Writing in a second or foreign language seems to be the most difficult language skill for language learners to acquire (Laksmi, 2006; Lestari, 2008; Negari, 2011). Some scholars proposed the implementation of SFL - genre based approach in teaching writing (Derewianka, 1990; Rothery, 1996). However, SFL genre based approach seems to be product or teaching outcomes oriented (Ahn, 2012; Emilia, 2011). Therefore, the concept of scaffolding in which possible supports the process of students' individual development is important to be emerged in the teaching stages of SFL - GBA (Bodrova \& Leong, 1998; Mulatsih, 2011). As a result, This study focuses on the issue of scaffoldings in the teaching of writing discussion texts based on SFL - Genre Based Approach. It particularly aims to investigate how scaffolding processes are implemented in the teaching of writing discussion texts based on SFL-GBA and how they improve the students' writing performance. The data rely on teaching and learning process in a classroom with six students in a tertiary level as the focus participants. The method used in the data analysis adopted a qualitative design with reference especially to the theory of the scaffolding and SFL-GBA. The results of analysis show that scaffolding processes are implemented in terms of macro and micro scaffoldings and able to improve the students' writing performance specifically in terms of social function, schematic structures, and language features of discussion genre. It is recommended that future related research should be conducted in more diverse of educational settings to see how scaffoldings are implemented in a variety of teaching practices.
\end{abstract}

Keywords: scaffolding, discussion texts, SFL, genre-based approach.

Writing in a second or foreign language seems to be the most difficult language skill for language learners to acquire (Laksmi, 2006; Lestari, 2008; Negari, 2011). Further, Laksmi (2006) explain that the difficulties are caused by some problems such as in getting ideas, organizing ideas, developing details, choosing correct words and structuring ideas in correct sentences, and maintaining paragraph unity.

To anticipate the problems, some scholars proposed the implementation of genre based approach in teaching 
writing (Derewianka, 1990, 2003; Hyland, 2007; Rothery, 1996). In genre based approach, the concept of teaching writing is teaching the students in the text level by involving the stages of teaching namely building knowledge of field, modeling, joint construction and independent construction (Emilia, 2011; Feez \& Joyce, 1998).

The implementation of genrebased approach follows the concept of scaffolding or teacher-supported learning (Hyland, 2004). The notion of scaffolding emphasizes the role of interaction with experienced others in learning, moving learners from their existing level of performance to a level of potential performance (Hyland, 2004; Walqui, 2006; Wood, Bruner, \& Ross, 1976).

The idea of scaffolding originally comes from the work of Jerome Bruner who defines scaffolding as a process of 'setting up' the situation to make the child's entry easy and successful and then gradually pulling back and handing the role to the child as he becomes skilled enough to manage it (Bruner, 1983). Over the past two decades, an increasing number of educators and researchers have used the concept of scaffolding as a metaphor to describe and explain the role of adults or more knowledgeable peers in guiding children's learning and development (Hammond, 2001; Stone, 1998). In the classroom context of classroom interaction, the term scaffolding has been taken up to portray the temporary assistance or support that teachers provide for their students in order to assist them to complete a task or develop new understandings, so that they will later be able to complete similar tasks alone (Dufficy, 2001; Hammond \& Gibbons, 2005; Michell \& Sharpe, 2005; Walqui, 2006; Wasik, 2008).
There are six principles of scaffolding proposed by Van Lier (2004) as cited in Hammond and Gibbons (2005). First, the principle of contextual support, exploration is encouraged in a safe, supportive environment; access to means and goals is promoted in a variety of ways. Second, the principle of continuity, mutual engagement is established. The encouragement and nonthreatening participation should be created in a shared community of practice. Third, the principle of intersubjectivity, task procedures are adjusted depending on actions of learners; contributions and utterances are oriented towards each other and may be constructed. Fourth, the principle of flow, skills and challenges are in balance; participants are focused on the task and are 'in tune' with each other. Fifth, the principle of contingency, it emphasizes the importance of teaching strategies being based on, and responsive to students' current understandings. Sixth, the principle of handover, there is an increasing role for the learner as skills and confidence increase; the teacher watches carefully for the learners' readiness to take over increasing parts of the action.

In general, there are two three types of scaffolding namely content scaffolding, strategic scaffolding, and procedural scaffolding (Luke, Freebody, Cazden, \& Lin, 2005). Content scaffolding refers to the guidance provided by the teacher in terms of concept maps and definitions to help the students learn and do a given task (Luke et al., 2005). In addition, there are two activities which are highlighted in the content scaffolding: explanation of the concepts, such as text types, ideas, and linguistic conventions; and explanation of the procedural knowledge such as text type format, conversion of grammar 
ENGLISH REVIEW: Journal of English Education Vol. 4, Issue 1, December 2015
ISSN 2301-7554

https://journal.uniku.ac.id/index.php/ERJEE rules. This scaffolding is used to answer 'what' and 'how' questions. In addition, strategic scaffolding refers to the strategies used to carry out the classroom interaction. It can be done by providing processes and approaches to achieve different task outcomes and to help the learners doing the task. For example, what the teachers need to do to help the students doing the task in as an individual or collaborative work. Moreover, procedural scaffolding deals with the provision of resources, materials, and tools for completing the task (Luke, Freebody, Lau, \& Gopinathan, 2005). This type of scaffolding is also used to answer 'how' questions. In the teaching and learning process, the teacher may provide pictures, authentic materials, and real objects.

Scaffolding is also categorized into macro and micro level (Hammond, 2001). A macro scaffolding sequence is a teaching learning unit designed around the curriculum cycle. Macro-level scaffolding is related to larger issues such as program goals and the selection and sequencing of tasks (Hammond \& Gibbons, 2005). In this scaffolding level, the teachers are required to be able to decide appropriate educational goals, and to articulate these goals both in terms of language goals and specific curriculum goals (Hammond, 2001). That is, they are able to make decisions about 'scaffolding what'. At macro level, there are five key elements of scaffolding: the teacher's goal, the teacher's understanding of the linguistic demands of the associated tasks, knowledge of the students and their current abilities and understandings, careful sequencing of tasks designed to develop the practices required to achieve the goal, and a gradual but constant shift of responsibility for task completion from teacher to student (Hammond, 2001; Walqui, 2006).

In addition, micro scaffolding occurs within the broader macro scaffolding. It is the teacher's supports which occur in the ongoing interaction (Hammond, 2001). Thus, it needs to be located within the macro scaffolding, so that there is a clear relationship between the sequential tasks and the teaching goals. This micro level scaffolding assists the teacher to focus on 'scaffolding how'. Teachers are encouraged to direct students' attention, at same points, to curriculum knowledge (content) and, at other points, to the kind of language (spoken or written) that they need control of in order to talk, read or write about that content (Hammond, 2001). The key element of micro scaffolding is the contingent nature of support. The teacher needs to monitor the students' understanding and ability constantly in order to determine the minimum support required (Firth \& Wagner, 1997). In response, the teacher is able to remove or supply the support constantly as needed to complete the task at hand.

Micro scaffolding which occurs during the teacher and the students' interaction can be identified as five types (Roehler \& Cantlon, 1997). However, Walqui (2006) categorized this type of scaffolding into six types. The five types of scaffolding classified by Roehler and Cantlon (1997) include offering explanation, inviting students' participation, verifying and clarifying students understanding, modeling of desired behavior, and inviting students to contribute clues. In addition, there are six types of scaffolding which include modeling, bridging, contextualization, schema building, re-presenting text and developing metacognition mentioned by Walqui (2006). Each type based on each expert will be elaborated as follows. 
As mentioned above, there are five types of scaffolding which occur within the interaction types (Roehler \& Cantlon, 1997). First, offering explanation refers to explicit statements adjusted to fit the learners emerging understanding about what is being learned (declarative or prepositional knowledge), why and when it is used (conditional or situational knowledge), and how it is used (procedural knowledge) (Roehler \& Cantlon, 1997). Second, inviting students' participation, after the teachers give illustrations of some the thinking, feelings, or actions then the learners are given the chance to participate in the occurring process (Roehler \& Cantlon, 1997). Third, verifying and clarifying students understanding, the teachers verify and clarify the students' comprehensive understanding through their responses (Roehler \& Cantlon, 1997). Fourth, modeling is defined as teaching behavior that show how one should feel, think or act in a certain situation (Roehler \& Cantlon, 1997).The last is inviting students to contribute to clues. In this type, the learners are asked to be involved to offer clues how to complete the tasks (Roehler \& Cantlon, 1997).

In addition, as mentioned above, Walqui (2006) proposes six types of scaffolding which occur during the classroom interaction. First, modeling includes giving clear examples of what is requested for imitation the texts by describing, comparing, summarizing, evaluating, and so on. Students need to be given clear examples for imitation (Larkin, 2001). When introducing a new task or working format, it is important for the learners be able to see or hear what a developing product looks like. From that point of view, guiding students through an interaction or first doing it together as a class activity is a necessary step. Therefore, to modeling tasks and activities and sharing examples of student work, it is important to model appropriate language use for the performance of specific academic functions.

Second, bridging is done to activate the students' prior knowledge so that students can produce written as well as spoken language. In addition, the important aspect of bridging is establishing a personal link between the student and the subject matter, showing how new material is relevant to the student's life, as an individual, here and now. Other ways of bridging include asking students to share personal experiences related to the theme that will be introduced in the lesson or assigned reading.

Third, contextualizing, in this type of scaffolding, the teacher can create analogies based on students' experiences. The language which is used in daily life and academic setting may be different. Thus, some of the learners find difficulties in understanding academic language. Then, teachers can continually search for metaphor and analogies that bring complex ideas closer to the students' world experience. This will help the students to understand what are being taught easily.

Fourth, schema building, it refers to clusters of meaning that are intertwined. It deals with the students' general knowledge which can lead them to the details. To construct the students understanding, the teacher needs to provide various activities. For example, in preparing for a reading assignment, teachers may ask students to preview the text by noting heads and subheads, illustrations and their captions, titles of charts, etc. In this way, students begin their reading with a general sense of the topic and its organization, with their 
schema already activated and ready to accept new connections.

The next is re-presenting text which refers to the ways used by the teachers to invite the students to check the language used in one text and the others. This can help the students to be engaged in the teaching and learning process so they can maximize their capacity. The less proficient students should be aided by their more proficient peers. Re-presenting text can also be done by changing the text being reading by them into role play, asking students to transform texts into letters, producing a poster of a story with a quote (Rajab, 2013; Tabar \& Alavi, 2013).

The last is developing metacognition which refers to the ways how the students manage their thinking, apply what they have learned, and have their understanding in completing the task.

In this research, the concept of scaffolding was implemented in the teaching of writing discussion texts under the concept of SFL - genre based approach. SFL - genre based approach which is implemented in Indonesia consist of four stages namely Building Knowledge of the Field, Modeling of the Text, Joint Construction of the Text, and Independent Construction of the Text (Emilia, 2011)

\section{METHOD}

This research was conducted at tertiary level, specifically at a university in Majalengka, West Java Province, adopting a qualitative design. The purposive sampling technique was used in determining the subjects of the research. Six students were purposively chosen as focus participants in this research. Research instruments utilized in this research included: (1) participatory classroom observations to gain the picture of the scaffolding processes implemented in the teaching writing of discussion texts based on SFLGBA; (2) documentation of students' texts to collect the data about the students' improvements in their writing of discussion texts; (3) and interviews to complete the data obtained from classroom observation and documentation of students' texts. Data analysis was performed through three stages: first, identifying the scaffolding processes implemented in the teaching process and the students' improvements in their texts. Second, reducing the data obtained in accordance with the purpose of the research. Third, mapping the patterns and relationships of each element as found in the previous two stages.

\section{RESULTS AND DISCUSSION}

The scaffolding processes as implemented in the teaching phases

The scaffolding processes as implemented in the teaching writing of discussion texts under SFL - genre based approach were categorized in terms of macro and micro levels. The result of this research showed that macro scaffoldings took place in all of the teaching phases. Meanwhile, the micro scaffolding took place in several phases of teaching, mostly in building knowledge of the field and modeling cycles. In joint construction of the text, micro scaffolding took place in some parts of teaching and learning activities. However, it did not take place in the independent construction of the text.

Macro scaffoldings revealed in this research were identified through: (1) teaching goals, (2) selection and sequence of tasks (3) and classroom organization. The teacher mentioned the teaching goals in each teaching session and they were also stated in the teaching 
document i.e. lesson plans. The teacher provided tasks based on the students' need. Moreover, the tasks were sequenced from the easiest to the complex one. In some activities, the students' were asked to work in pairs or groups. For instance, in joint construction of the text, the students' were asked to write a discussion text in group.

Micro scaffoldings revealed in this research included: (1) offering explanation; (2) modeling; (3) bridging; (4) inviting students' participation; (5) inviting students to contribute clues; (6) schema building; (7) verifying and clarifying students' understanding; (8) re-presenting text; (9) contextualizing; (10) and developing metacognition. Offering explanation

This type of scaffolding which appeared in the teaching phases was in forms of declarative and procedural knowledge. Declarative knowledge can be identified when the teacher explained the discussion text which was being learnt by the students explicitly, such as explained the schematic structure and the language features of discussion genre.

In the following example, the teacher provided declarative knowledge when explaining the schematic structure of discussion genre.

Teacher : Do you know the structure of discussion text?

Students : (no response)

Teacher : hmm, look at this. If you want to write a discussion text, so you need to present the issue, the arguments for, the argument against, and the conclusion. Those are the structures of a discussion text.

Now, look at the example of discussion text, the see the structures of the text!

In the excerpt above, the teacher asked whether the students know the structure of discussion text or not. The students gave no response so the teacher explained the structure of discussion text explicitly. Then, the teacher checked the students' understanding about what had been explaining by asking the students to analyze the schematic structure of the text model. This activity is very helpful to increase the students' understanding of the schematic structure of discussion text (Roehler \& Cantlon: 1997).

Procedural knowledge as the other form of the offering explanation was also identified in this teaching cycle. It can be identified when the teacher mentioned how a discussion text should be constructed to achieve its purpose. The example can be seen in the following excerpt.

Teacher : As you know that the social function of discussion text is to discuss an issue from different point of view. Thus, to achieve the purpose, we need to construct the text based on the appropriate structure.

Can you mention the structure of a discussion text?

Students : Yes.

Teacher : What are they?

Students : Issue, arguments for, argument against, and conclusion.

Teacher : Good. So, to meet the purpose of discussion text we need to present the arguments for which support the issue and the arguments against which oppose the issue. 
In the excerpt above, the teacher explained how the social function or the purpose of the text can be achieved. This type of offering explanation can be categorized into procedural knowledge explanation since it provided explicit statements to help the learners emerging their understanding on how to achieve the purpose of the text (Roehler \& Clanton, 1997).
Inviting students' participation

The next type of micro scaffolding found in the teaching phases was inviting students' participation. This type of scaffolding can be identified when the teacher give the students opportunities to join the process that was occurring. The example of this type of scaffolding is presented in the following excerpt.

In this example, the teacher invited the students participation by asking the student opinion about what was being discussed.

Teacher : So, which one is the argument for?

Students : (raising their hand)

Teacher : Okay, Olive. So, which one is the argument for?

Olive : The second paragraph. The first reason why the corruptors should be given the death penalty because they cause difficulties for economic development.

In the interaction above, it can be observed that the teacher invited students' participation by asking the students to mention which one is the argument for in the text. Since the students participated actively during the teaching and learning process so it was not difficult to invite their participation during the teaching and learning process in this teaching cycle.

\section{Verifying and clarifying students' understanding}

This type of scaffolding can be identified when the teacher checked the students' emerging understanding. The excerpt below is presented the example on how the teacher verified and clarified the students' understanding. After explaining about the use of connective conjunction as one of 1 the language features of discussion text, the teacher verified and clarified the students understanding by asking some questions.

Teacher : Any question about connective conjunction used in discussion text?

Students : (no response)

Teacher : Andi, please take a look to the example text! Can you mention the example of connective conjunction in the text?

Andi : For example, if we want to continue to the second paragraph, we can use "Below are the discussion of argument for and against the death penalty"

Teacher : Okay, good. What else?

Student : (raising his hand)

Teacher : Yogi, please! 
Yogi : Before mention the arguments we can say "the first reason why we support death penalty is" or "the first reason why we oppose the death penalty is"

Teacher : Yes, before mentioning the arguments we can say that.

In the excerpt above, the teacher verified and clarified the students understanding illustrated in the italic sentences by asking some questions and give feedback to the students' responses. When the students shared their understanding or answered the questions correctly it means that the students were acknowledged what was being discussed.

\section{Modeling}

Modeling which was found in this teaching cycle of this present study was in form of demonstration. The demonstration provided by the teacher includes providing several models of discussion genre.

Teacher : Now, I have two examples. Read these texts first! Have you finished read those texts?

Students : Yes.

Teacher : Comparing these texts, which one do you think is a discussion genre?

Students : The second text, the first text...

Teacher : Yes, Andi. Why do you say that the first text is a discussion text?

Andi : Because we can found the argument for and against the issue in the text.

Teacher : How about you, Olive?

Olive : I agree with Andi.

Teacher : The first text is the example of a discussion text. How about the second text? What type of text is it?

Students : (no response)

Teacher : Can you find the discussion about the issue?

Students : no

Teacher : So, what can you find in the text?

Students : The elaboration of arguments.

Teacher : Okay, this text is the example of hortatory exposition text.

Now, look at the first text, work in group and analyze the schematic structure of the text!

In the interaction above, the teacher gave two models of different texts to give a real example of text being learned by the students. The students were asked to compare both text and decided which one was a discussion text. This activity can give some benefits for the students since they need to be given clear examples of what is requested of them for imitation when they are introducing to a new task so they are able to develop product looks like (Walqui, 2006).

Inviting students to contribute clues

This type of scaffolding was identified in the teaching phases when the teacher encouraged the students to contribute clues how to complete the tasks. The following excerpt provides the example on how the teacher provided this type of scaffolding. 
Teacher : After reading the text. So, why do people agree with the death penalty?

Students : (raising their hands)

Teacher : Okay, Yogi.

Yogi : It is related to deterrence effect.

Student : Miss...

Teacher : Yes, Andi.

Andi : Justice.

Teacher : Why justice?

Andi : Because it will make the victim's family trauma when they know the perpetrator still alive.

Teacher : How about deterrence?

Yogi : The perpetrator cannot commit another crime or the potential criminal will think twice.

In the excerpt above, the teacher invited the students to contribute clues as illustrated in the italic sentences, the teacher guided the students to share their arguments by asking them question "why do people agree with death penalty?" . Then the students gave responses to the teacher question. In line with that, Roehler and Clanton (1997) say that this type of scaffolding can be valuable since the students were persuaded to offer clues and verbalized the process together with the teacher.

Bridging

Bridging is provided by the teacher to activate students' prior knowledge (Walqui, 2006). This type of scaffolding could be identified when the teacher asked the students to share their experiences related to the theme that will be introduced in the lesson.

Teacher : Do you still remember what type of texts that you have learned in the previous writing course or when you were in senior high school?

Students : Letter, CV...

Teacher : In senior high school?

Students : Narrative, descriptive

Teacher : What else?

Students : Recount..

Teacher : How about discussion text?

Students : (no response)

Teacher : Have you learned about discussion text?

Students : No.

In the excerpt above, the teacher tried to connect what is going to be learned by the students with their prior knowledge or experience. The teacher asked the students whether they have learned about discussion text or not.

\section{Schema building}

This type of scaffolding was found in this teaching phases. It can be identified when the teacher asked the students to preview the text in the preparation for reading so the student began their reading with the new concept which they need to familiar with. In the following example, schema building 
occurred when the teacher directed the students to the most important part which would be discussed in the following activity. It can be seen in the following excerpt.

Teacher : Before finding out the elaborations, what you need to do is mark each part of this text, which one is the issue, the argument for, the argument against, and the conclusion.

Students : Yes, Miss.

Teacher : Okay, go on.

In the excerpt above, it was revealed that the teacher asked the students to capture the broader part before portrait the details. This is in line with the suggestion proposed by Walqui (2006) that schema building is important because the student must have "a general knowledge of the broad picture before studying the details." This schema building is also useful since it will help the learner to focus on important information to come.

\section{Contextualizing}

This type of scaffolding was found in the teaching phases can be identified when the teacher gave analogies related to the topic being discussed. This can be seen in the following example:

Teacher : Talking about discussion genre, it looks like two sides of a coin. There will be different arguments related to the issue. In discussion texts, we need to present arguments that support and oppose the issue. Any questions so far?

Students : Which arguments that should be presented as the first one?

Teacher : Commonly, arguments that support the issue come first.

In the excerpt above, the teacher gave an analogy about two sides of a coin. The teacher said that discussion genre looks like a coin which has two sides. In discussion genre, an issue is also presented in two different points of views.

\section{Representing Text}

This type of scaffolding can be identified when the teacher invited the student to check the language used in one text and the others. The example can be seen in the following expert:

Teacher : Now you have two different texts. What you need check the language features of each text. Then analyze which text is discussion text?

In the excerpt above, the teacher asked the students to analyze the language features of two different texts. As mentioned by Walqui (2006) this can help students to maximize their capacity in understanding the genre being discussed.

\section{Developing Metacognition}

This type of scaffolding can be identified in the teaching phases. For instance, the teacher gave a model and practice as a whole class before students worked in pairs or small groups. 
Teacher : Now, look at this example of discussion text. The first paragraph is the issue. The issue presents the topic that we are going to discuss in the next paragraph. The second and third paragraph provides arguments related to the issue. The second paragraph is argument for which support the issue. Meanwhile, the next paragraph consists of argument against which oppose the issue. The last is conclusion.

Now look at the second text. Can you mention which one is the issue?

Students : The first paragraph.

Teacher : How do you know that the first paragraph is the issue?

Bambang : Because it presents the topic that elaborated in the next paragraph.

In the excerpt above, it can be seen that the teacher provide an exercise in a whole class before asking the students to analyze texts in pairs and groups.

The students' improvements in writing of discussion texts

The students' improvements in writing of discussion texts were reflected in the final texts in terms of social function, schematic structures, and language features of discussion genre. In the diagnostic texts, the students' text did not indicate that the students had sufficient knowledge about the topic of the essay and discussion genre.
The students' improvement in term of social function

In terms of social function, the data reveal that most of the students are able to fulfill the social purpose of discussion genre; that is, to discuss an issue in the light of some kind of "frame" or position and provide more than one point of view on an issue. This result is different from the students' diagnostic texts in which all of them did not discuss the issue from different point of view.

As the example, the improvement also happened to student from the low achiever - Olive - who is able to show the social purpose of a discussion genre. In the diagnostic text she only mentioned that she agreed with the implementation of death penalty without the elaborations of arguments from different point of view. The following example is her issue in the diagnostic text:

The Death Penalty of Drugs Dealer
Now in Indomesia has decioded the death penathy fro
the drugs dealer. It can broken the futuse of user

Meanwhile, the issue in the final text shows that she is going to elaborate the argument in two points of view. The way on how she presents the issue in the final text can be seen as follow. 


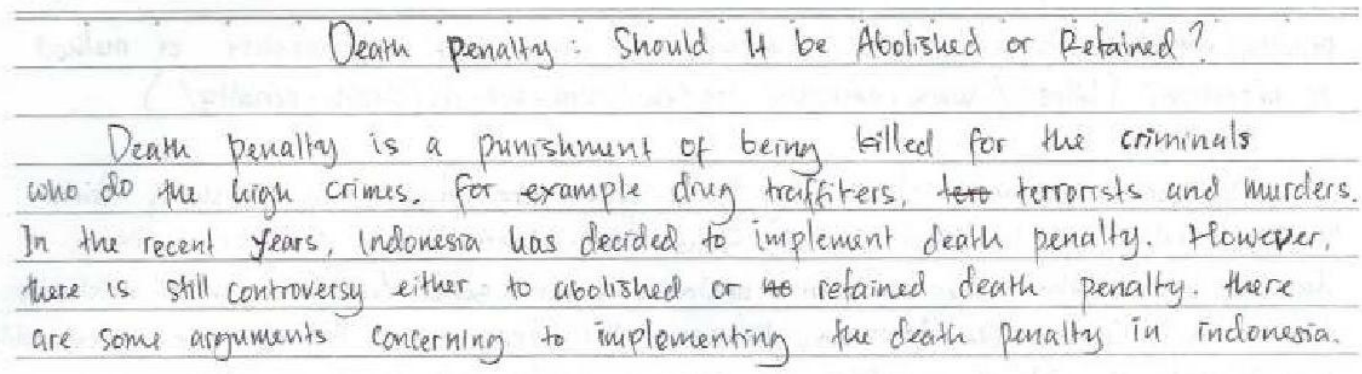

Looking at the issue presented by Olive in the diagnostic text and final text, it shows the capacity of her understanding about the social function of discussion genre increases. This improvement can be seen on how she gave the title for her text and mentioning that a discussion text is talking an issue in different point of view. It is marked by the word 'controversy' and in the next following paragraph she discussed the issue based on two sides.

The students' improvement in term of schematic structures

In terms of generic structure, each text produced by the students in the final text consists of same recommended generic structure of discussion genre; issue, arguments for, arguments against, and conclusion. It indicates that the students organized their text properly. This result is different from the texts constructed in the diagnostic test in which most of the students did not know the generic structure of discussion genre.The text written by the student in the diagnostic test did not show his understanding of the social function and the schematic structure of a discussion text. Therefore, the text cannot be considered as a discussion text.

The Summary of Schematic Structures Produced by the Students

\begin{tabular}{|c|c|c|c|c|c|c|c|}
\hline \multicolumn{4}{|c|}{ Diagnostic Text } & \multicolumn{4}{|c|}{ Final Text } \\
\hline Issue & $\begin{array}{l}\text { Arg. } \\
\text { For }\end{array}$ & Arg. Against & Con. & Issue & $\begin{array}{l}\text { Arg. } \\
\text { For }\end{array}$ & $\begin{array}{c}\text { Arg. } \\
\text { against }\end{array}$ & Con. \\
\hline- & - & - & - & $\sqrt{ }$ & $\sqrt{ }$ & $\sqrt{ }$ & $\sqrt{ }$ \\
\hline
\end{tabular}

The students' improvement in term of language features

In terms of linguistic features, the students improve their understanding on the linguistic features of discussion text. This improvement can be seen from the difference between the result of diagnostic and final text. For example, the texts constructed by the students in the diagnostic text are absence of technical terms, experts' opinion, verbal process, and nominalization. Moreover, there are some errors in using the connective conjunction. Meanwhile, in the final text, both of them show the progress. The linguistic features of discussion genre can be found in their texts. Specifically, the improvements are implemented from the existence of linguistic features including the use of modality, the use of process types, the use of nominalization, the use of connective conjunction.

Concerning to the use of modality, the modality can be found in both of the diagnostic and final text. However, in 
ENGLISH REVIEW: Journal of English Education Vol. 4, Issue 1, December 2015
ISSN 2301-7554

https://journal.uniku.ac.id/index.php/ERJEE the final text the student tended to use more modality. This indicates the student's attitude as the author.

Relating to the processes types used in the texts, in the diagnostic text, the verbal processes were not found. However, in the final text, all of the process types were found. In the diagnostic text material process occurrence was the highest one but in the final text the verbal process was the highest one.

In terms of the use of nominalization in the texts, looking the number of the occurrence of nominalization in the final text, there is an improvement. In the diagnostic text, the process of nominalization was not found. However, it was found twice in the final text.

Concerning the use of connective conjunction in the texts, in the diagnostic text, the students used seven conjunctions. However, it was significantly improve in the final text. In the final text, the students used not only to add information or to show the contrary but also used the connective conjunction associated with reasoning 'The second reason.....'.

\section{CONCLUSION}

This research was focused on two main problems. The first is the implementation of scaffolding processes in the teaching writing of discussion texts under the concept of SFL-Genre Based Approach. The second is the students' improvements in writing discussion texts as resulting from the scaffolding processes.

Related to the implementation of scaffolding processes in the teaching writing of discussion texts under the concept of SFL-Genre Based Approach, the results of this research revealed that the scaffolding processes as reflected in teaching cycles can be categorized into macro and micro scaffoldings. Macro scaffolding deals with the teaching goals, classroom organization, and the selections and sequences of the task. This category was found in all of the teaching cycles. In addition, micro scaffolding deals with the scaffolding provision in the classroom interaction. Micro scaffolding as reflected in the teaching cycle took place in the building knowledge of field, modeling of the text, and joint construction of the text. There are ten types of micro scaffolding which were found in the present study include offering explanation, modeling, bridging, inviting students' participation, inviting students to contribute clues, schema building, and verifying and clarifying students' understanding, re-presenting text, contextualizing, developing metacognition. These types of scaffolding mostly took place in modeling of the text cycle.

In the aspect of students' improvements in writing discussion texts, the data from students' texts showed the scaffolding processes as reflected in the teaching cycles improve the students writing performance in writing a discussion text in terms of social function, schematic structures, and language features. Therefore, it can be said that scaffolding processes have been feasible to be applied in a teaching and learning process, especially in teaching writing under SFL-Genre Based Approach concept.

\section{REFERENCES}

Ahn, H. (2012). Teaching writing skills based on a genre approach to L2 primary school students: An action research. English Language Teaching, 5, 2-16. http://doi.org/10.5539/elt.v5n2p2 
Bodrova, E., \& Leong, D. J. (1998). Scaffolding emergent writing in the zone of proximal development. Literacy Teaching and Learning, 3, 1-18.

Bruner, J. (1983). Child's talk. New York: Norton.

Derewianka, B. (1990). Exploring how texts works. Sydney: Primary English Teaching Association.

Derewianka, B. (2003). Trends and issues in genre-based approaches. RELC Journal, 34, 133-154. http:// doi.org/10.1177/00336882030340 0202

Dufficy, P. (2001). Scaffolding and assisted performance in multilingual classrooms. Journal of Educational Enquiry, 2, 33-49.

Emilia, E. (2011). Pendekatan genre based dalam pengajaran bahasa Inggris: Petunjuk bagi guru. Bandung: Rizqi Press.

Feez, S., \& Joyce, H. (1998). Text-based syllabus design. Sydney: National Centre for English Language Teaching and Research.

Firth, A., \& Wagner, J. (1997). On discourse, communication, and some fundamental concepts in SLA research. Modern Language Journal, 81, 258-300.

Hammond, J. (2001). Scaffolding and language. In scaffolding teaching and learning in language and literacy education. Newton NSW: Primary English Teaching Association.

Hammond, J., \& Gibbons, P. (2005). Putting scaffolding to work: The contribution of scaffolding in articulating ESL education. Prospect, 20, 6-30.

Hyland, K. (2004). Genre and second language writing. Ann Arbor: University of Michigan Press.

Hyland, K. (2007). Genre pedagogy: Language, literacy and L2 writing instruction. Journal of Second Language Writing, 16, 148-164. http://doi.org/10.1016/j.jslw.2007.07.00 5

Laksmi, E. D. (2006). Scaffolding students' writing EFL Class: Implementing process approach. TEFLIN Journal, 17, 144-156.
Larkin, M. J. (2001). Providing support for student independence through scaffolded instruction. Teaching Exceptional Children, 34, 30-34.

Lestari, L. A. (2008). The interactional approach to the teach-ing of writing and its implications for second language acquisition. Teflin Journal, 19, 42-56.

Luke, A., Freebody, P., Cazden, C., \& Lin, A. (2005). Singapore pedagogy coding manual. Singapore: Centre for Research for Pedagogy and Practice.

Luke, A., Freebody, P., Lau, S., \& Gopinathan, S. (2005). Towards research-based innovation and reform: Singapore schooling in transition. Asia Pacific Journal of Education, 25, 5-28.

Michell, M., \& Sharpe, T. (2005). Collective instructional scaffolding in English as a second language classrooms. Prospect, 20, 31-58.

Mulatsih, S. (2011). The use of scaffolding technique to improve the students' competence in writing genre-based texts. Parole, 2, 101-109.

Negari, G. M. (2011). A study on strategy instruction and EFL learners' writing skill. International Journal of English Linguistics, 1, 299-307. http:// doi.org/10.5539/ijel.v1n2p299

Rajab, H. (2013). Developing speaking and writing skills of L1 Arabic EFL learners through teaching of IPA phonetic codes. Theory and Practice in Language Studies, 3 , 653-659. http:// doi.org/10.4304/tpls.3.4.653-659

Roehler, L. R., \& Cantlon, D. J. (1997). Scaffolding: A powerful tool in social constructivist classrooms. In Scaffolding Student Learning Instructional Approaches and Issues. Canada: Brookline Books Inc.

Rothery, J. (1996). Making changes: Developing educational linguistics. In Literacy in Society. New York: Addison Wesley Longman Limited.

Stone, A. (1998). The metaphor of scaffolding: Its utility for the field of learning disabilities. Journal of Learning Disabilities, 40(3), 344-364.

Tabar, N. A., \& Alavi, S. M. (2013). A comparative study of the effects of task- 
ENGLISH REVIEW: Journal of English Education Vol. 4, Issue 1, December 2015

based writing under different pre-task planning conditions on intermediate EFL learners' written performance in personal and decision-making tasks. International Research Journal of Applied and Basic Sciences, 5(8), 970-978.

Walqui, A. (2006). Scaffolding instruction for english language learners: A conceptual framework. The International Journal of
ISSN 2301-7554

https://journal.uniku.ac.id/index.php/ERJEE

Bilingual Education and Bilingualism, Vol. 9, No. 2, 159-180.

Wasik, B. (2008). When fewer is more: Small groups in early childhood classrooms. Early Childhood Education Journal, 35, 515-521.

Wood, D., Bruner, J. S., \& Ross, G. (1976). The role of tutoring in problem solving. Journal of Child and Psychiatri \& Allied Discipline, 17, 89-100. 